\title{
50. How can finance be used to combat climate change?
}

\section{Alain Grandjean}

On 23 September 2014, United Nations Secretary-General Ban Ki-moon invited world leaders (representatives of governments, finance, business and civil society) to New York for a climate summit as part of the preparations for COP21, which would take place in Paris in December 2015. This meeting was a notable success; coalitions of investors ${ }^{1}$ were formed and made commitments to measure the carbon footprint of their portfolios and gradually reduce it. A little later, it was in Montreal that other investors became involved. ${ }^{2}$ This is when "green finance" was born, and we will argue here that green finance requires serious regulation for its promises to be fulfilled.

\section{THE FIGHT AGAINST - AND ADAPTATION TO - CLIMATE CHANGE GENERATES SIGNIFICANT INVESTMENTS}

Investment needs (particularly in infrastructure) are regularly estimated at all levels. In 2014, the report from the Global Commission on the Economy and Climate $^{3}$ estimated these needs at 90 trillion dollars worldwide over the period 2015-30, while insisting that taking climate into account would only cost an additional 5 per cent. In 2016, the European Commission estimated the needs in transport, "low-carbon" energy production, networks, building renovation and industry for the period 2021-30. ${ }^{4}$ Adding the European Investment Bank (EIB) estimates ${ }^{5}$ for water management and flood protection, waste management, resilient urban infrastructure and research and development in transport and renewable energy, it amounts to more than 1300 billion euros per year (more than 8 per cent of the European Union's 2017 GDP). As for the financing gap, that is, the difference between the amount of the investments made and the amount of those that would need to be made, it is, for these sectors, more than 300 billion euros per year. This is in addition to the transformation that is needed in our agricultural model, the sustainable management of forests and natural areas, pollution control activities and investment in a circular economy. In addition to these amounts, there is also the need to adapt our 
infrastructures and buildings to "embedded" climate change (regardless of any possible future reduction in our greenhouse gas emissions), which will already have a very negative impact on our living conditions.

\section{THE PRICE OF CARBON: THE DUAL NEED TO INCREASE IT BUT TO ACT ON OTHER LEVERS WITHOUT DELAY}

We will not return here to the need to raise the price of carbon. The current level of carbon tax or price of quotas in regions such as the European Union, where a market for quotas is in place, is generally far too low (with the exception of certain Nordic countries that have introduced a much higher carbon tax alongside quotas). To take just one example, an official committee chaired by Alain Quinet ${ }^{6}$ estimated that the target price to put the French economy on a path compatible with the Paris Agreement was 250 euros per tonne of $\mathrm{CO}_{2}$ in 2030 and almost 800 euros in 2050. This is far from the current case (less than 50 euros for the carbon tax, and less than 30 euros for the quota price). Setting up carbon taxes ${ }^{7}$ at a high enough level in each country is still essential, of course, but obviously very politically difficult: the climate emergency therefore requires taking additional measures that are accessible.

In the strictly financial world, several specific levers can be used. We will refer here to those that are currently being debated and which seem to us to be discriminatory, but we will begin by showing the limits of market players' action and of their enthusiasm for green finance.

\section{Better Informed Markets: The Illusory Mantra of Green Finance}

According to the prevailing and completely theoretical representation of the economy, markets are efficient as soon as they are properly informed. This representation is largely misconceived: in practice, financial markets are not efficient. $^{8}$

Mark Carney, then Chairman of the Financial Stability Board, was officially asked by the G20 Finance Ministers in 2015 whether the climate risk could be systemic in nature. His answer, given in a speech called "Breaking the tragedy of the horizon" at the headquarters of the insurer Lloyd's of London, was affirmative and unambiguous. ${ }^{9} \mathrm{He}$ classified climate risks into three categories: transition risks (related to the "decarbonization" of the economy that can cause carbon assets to lose value and turn them into stranded assets) ${ }^{10}$ physical risks related to climate change itself, and legal risks (resulting from victims' legal actions against those responsible for climate change). But he concluded this brilliant speech by emphasizing the need for financial investors 
to be better informed about these risks, thus simply endorsing the prevailing thesis mentioned above.

Since then, several initiatives have been carried out or are underway to meet this expectation. Following Mark Carney's speech, an international working group chaired by Michael Bloomberg, the Task Force on Climate-related Financial Disclosures (TCFD), produced a first set of general and sectoral recommendations in June 2017, ${ }^{11}$ followed by a second report in June 2019. In December 2016, the European Commission launched a working group, the High-Level Expert Group, which issued its conclusions ${ }^{12}$ in January 2018. The Commission's Action Plan on Sustainable Finance, adopted in March 2018, was based on its conclusions. The concrete initiatives concerned only information management and this on four subjects: the establishment of a clear and detailed Community classification system - or taxonomy - for sustainable activities, aimed at creating a common language for all actors in the financial system; the definition of standards for green bonds; for low-carbon indices; ${ }^{13}$ and for the "metrics" to be used.

It is not possible today to make an exhaustive assessment of these various initiatives because the process is ongoing and its implementation is still partial. They have certainly had the merit of causing investors to take an interest in a subject that seemed unrelated to their profession until recently - on the grounds, also doctrinal, that finance would be neutral, which is obviously wrong. ${ }^{14}$ Some of these investors are making green finance (notably through the issuance of "green bonds") an area for development. However, we do not see how and why an investor, whose decisions are driven by the expected financial return, would integrate a risk that he or she always perceives as long term (even if he or she might think that this term is close given the observed climate change). This is what Mark Carney made explicit when he spoke of the "tragedy of the horizon". To put it even more broadly, it is not market finance, which is short term in essence, that will in itself "save the world".

There are also a number of factual elements that show that, beyond the rhetoric, inaction is quite general. To date, portfolios have not been significantly reallocated to "low carbon". The share of "green" assets - or so-called greens ${ }^{15}$ - remains low. ${ }^{16}$ Investment in fossil fuels remains at very high levels. As Philippe Zaouati ${ }^{17}$ (CEO of Mirova, the socially responsible investment fund of Natixis, the corporate and investment bank of the Banque Populaire et Caisse d'Epargne group) observes, passive management ${ }^{18}$ (the majority of asset managers) "remains from $95 \%$ to $98 \%$ indexed on past indices and not on indices compatible with a $2{ }^{\circ} \mathrm{C}$ trajectory". In addition, in the insurance sector, a recent study by the think tank Shift Project ${ }^{19}$ shows the schizophrenia that prevails in this sector. Admittedly, "[i]nstitutions publish reports on climate risk, which are highly documented and well argued". But "when these same institutions (or others) publish a report on the insurance sector and on its risks 
in general, based on global analyses, the climate risk very often disappears from the radar. There is talk of 'macroeconomic', 'systemic' or 'holistic' risk, but there is no mention of climate". ${ }^{20}$ This means that in fact these institutions do not consider that at this stage this risk is "material"; in other words, that the risks may result in a financial loss in the time frame of their analysis.

\section{The Need for Public Intervention in the Financial Sector}

These findings should encourage public authorities and regulators, who are responsible for the general interest, to move from information recommendations to active public policies and binding rules (and in practice regulations). We will not focus here on the obvious need to reduce and then eliminate fossil fuel subsidies, ${ }^{21}$ which amounted to 340 billion dollars in 2017 for 76 countries, by implementing support policies in accordance with the countries and the specific constraints of the citizens concerned. Three other options are to be considered.

\section{Ban public banks from financing fossil fuels}

The action of public banks is by definition directly controlled by public authority, which can therefore ask them to stop financing activities related to fossil fuels. The effect is twofold, involving first their own financing, but second, the financing of private banks when they participate in syndications with them. This is particularly the case for development banks.

In 2015 the Canfin-Grandjean report, ${ }^{22}$ submitted to the President of the French Republic in preparation for COP21, recommended in particular that "each development bank should set itself a ' $2^{\circ} \mathrm{C}$ roadmap' showing its contribution to the $2^{\circ} \mathrm{C}$ trajectory and the carbon content of its portfolio of financed projects as well as its approach to making its portfolio of operations resilient". It is possible to go further today. The EIB announced on Thursday 14 November 2019 that it would no longer finance new fossil fuel projects, including gas, from 2022 onwards and that it would commit to dedicating 50 per cent of its financing to environmental projects by 2025 . The EIB is thus paving the way for a significant reduction in fossil fuel financing.

\section{The greening of monetary policy}

In 2012, the European Central Bank (ECB) saved the eurozone. The bank's president, Mario Draghi, announced at that time that the ECB would buy, without limit, sovereign bonds from the euro area, thus putting an end to the speculation that was endangering it. This programme of "Outright Monetary Transactions" was not provided for in the Treaties; it was challenged in the German Constitutional Court and before the European Court of Justice, but 
was validated by these two bodies. ${ }^{23}$ This is proof that necessity prevails and that it is possible to be imaginative in monetary matters.

This operation was followed in 2015 by so-called "non-conventional" QE (quantitative easing) operations, which were supposed to facilitate the exit from creeping deflation. The limits and disadvantages of QE are today under discussion: it has no effect on the real economy; negative interest rates are favourable to speculative transactions and a "zombie" economy. But QE could be a powerful lever for the ecological transition and the recovery of the - green - economy, particularly because of the priority given by the new European Commission to the fight against climate change and to a Green Deal. ${ }^{24}$ It should also be noted that, contrary to popular belief, the ECB has full legitimacy to take action on the climate. ${ }^{25}$ Article $127(1)$ of the Treaty on the Functioning of the European Union (TFEU) states that "without prejudice to the objective of price stability, the ESCB [European System of Central Banks] shall support the general economic policies in the Union with a view to contributing to the achievement of the objectives of the Union as laid down in Article 3 of the Treaty on European Union". For its part, Article 3 of the TEU explicitly includes the objective of "sustainable development of Europe, based" - among other factors - on "a high level of protection and improvement of the quality of the environment". Thus, sufficient elements of legality for the ECB to develop green monetary policies are already included in the TFEU.

How do we proceed in practice? We know that public institutions cannot benefit from financing from the ESCB, with the notable exception of public investment banks. These banks may have access, under the same conditions as private banks, to the ECB's counter (Article 123(2) of the TFEU). National and European authorities could therefore launch ambitious investment programmes $^{26}$ financed by a network of public banks (the EIB, the European Bank for Reconstruction and Development [EBRD] and national banks such as Kreditanstalt für Wiederaufbau [KfW] in Germany and the Banque Publique d'investissement [BPI] and la Banque Postale in France), which would themselves be financed by the issuance of bonds acquired by the ECB in significant volumes. ${ }^{27}$ This proposal ${ }^{28}$ would not require a reversal of the ban on monetary financing for states and could be compatible with the continuity of the principle of central bank independence, which is essential for such a proposal's crucial acceptance by German population. ${ }^{29}$

In parallel with this climate-focused buyback operation, the ECB should stop holding "carbon assets" in the securities it buys or accepts as collateral. Altogether, it would thus launch a real "green-QE", an operation that guarantees the financing of green and stops the financing of fossil fuels. 


\section{Penalize banks that finance the fossil fuel economy}

However, this "green-QE" will not have a direct effect on private banking operations. It should be recalled that investments in fossil fuels remain considerable. The International Energy Agency (IEA) ${ }^{30}$ estimated these investments at a total of 800 billion dollars for 2018, slightly higher than in 2017 . The players in the sector are very powerful: according to Moody's Investors Services, the profits in 2018 of the five Western majors (Royal Dutch Shell, ExxonMobil, Chevron, Total and British Petroleum) were 89 billion dollars. Saudi Aramco's profits amounted to 110 billion dollars. Although these companies are powerful, and unfortunately helped by massive public subsidies, they need bank financing (for all their operations, not just investments), which they can nowadays (far too) easily find. In 2018, the world's 33 largest banking institutions provided them with a total of 600 billion dollars in financing. ${ }^{31}$

It is therefore advisable to strongly encourage banks to move out of financing the fossil fuel economy. This can be done, for example, by introducing a penalty factor, a "brown penalizing factor" in the calculation of the equity ratio, the risk-weighted assets (RWAs), ${ }^{32}$ which would reduce their profitability on equity if they continue to participate in financing carbon assets (both directly and in loans to investors). This idea was endorsed by the governor of the Banque de France in April 2019. ${ }^{33}$

The idea was analysed by researchers Jakob Thomä and Kyra Gibhardt. ${ }^{34}$ Natixis, decided in 2019 to simulate what could be achieved by a system called the Green Weighting Factor (with a bonus for green financing and a penalty for fossil fuel financing), thus anticipating a decision that could be taken at European level. It should be recalled that while the Basel Committee is a forum for drawing up proposals on banking regulation, it is the states and the European Union that decide on their transcription into regulations - which have sole legal force. In this case, the transcription of the Basel III agreements into a regulatory package ${ }^{35}$ was adopted by the European Parliament in April 2019. The next version of this package could and should therefore include consideration of the climate crisis.

This approach could also be applied to insurance companies, with Pillar 1 of the Solvency II framework being devoted to the capital requirements of these companies. Insurance companies are also big investors. How they are going to be regulated is of primary importance to the climate.

\section{CONCLUSION}

Financial investors are becoming aware of climate change and are beginning to consider that it could have an impact on their profession. However, they have not significantly changed their investment or disinvestment decisions, which are crucial in the current battle. Public authorities, particularly at European 
level, can accelerate the effective consideration of climate issues in these decisions. These authorities have powerful levers in their hands. It is up to them to use these as soon as possible.

\section{NOTES}

1. Like the Portfolio Decarbonization Coalition; see https://unepfi.org/pdc/, accessed 24 August 2020.

2. See the Montréal Carbon Pledge at https://montrealpledge.org/, accessed 24 August 2020.

3. This commission was chaired by Felipe Calderon, Nicholas Stern and Ngozi Okonjo-Iweala. It has been continued in the "New Climate Economy" project. See https://newclimateeconomy.net, accessed 24 August 2020.

4. "Commission staff working document. Impact assessment. Accompanying the document Proposal for a Directive of the European Parliament and of the Council amending Directive 2012/27/EU on Energy Efficiency" (2016), Table 22, accessed 20 August 2020 at https://eur-lex.europa.eu/legal-content/EN/TXT/?uri $=$ CELEX\%3A52016SC0405.

5. European Investment Bank, Restoring EU Competitiveness 2016 Updated Version, accessed 20 August 2020 at https://www.eib.org/attachments/efs/restoring_eu competitiveness_en.pdf.

6. See https://www.strategie.gouv.fr/publications/de-laction-climat, accessed 24 August 2020.

7. See, for example, the report published in 2017 by Nicholas Stern and Joseph Stiglitz, at https://www.carbonpricingleadership.org/report-of-the-highlevel -commission-on-carbon-prices, accessed 24 August 2020.

8. See, for example, Nicolas Bouleau's uncompromising analysis at http://www .nicolasbouleau.eu/critique-de-lefficience-des-marches-financiers/, accessed 24 August 2020.

9. See https://www.fsb.org/wp-content/uploads/Breaking-the-Tragedy-of-the -Horizon- $\%$ E2\%80\%93-climate-change-and-financial-stability.pdf - and here, its translation into French: https://alaingrandjean.fr/2015/11/11/mettre-fin-a-la -tragedie-des-biens-lointains-changement-climatique-et-stabilite-financiere/, both accessed 24 August 2020.

10. What they are, in fact, if we take climate change seriously. See Claude Henry's article on this subject, at https://www.lemonde.fr/idees/article/2018/09/05/claude -henry-trois-mesures-pour-sortir-du-desastre-ecologique_5350348_3232.html, accessed 24 August 2020.

11. See https://www.fsb-tcfd.org/publications/final-recommendations-report/, accessed 24 August 2020.

12. See https://ec.europa.eu/info/publications/180131-sustainable-finance-report_fr, accessed 24 August 2020.

13. We will return to this subject, whose importance is sometimes underestimated.

14. Two arguments are sufficient to demonstrate this. First, finance necessarily favours short-term profitable assets, simply because of the capitalization calculation; and second, it focuses by mimicry on the expected returns of stock market indices, which reflect the current economy, which is far too carbon intensive.

15. Are "green bonds" an illusion? This is what Ivar Ekeland and Julien Lefournier think and demonstrate in this convincing indictment, at http://www.chair-energy 
-prosperity.org/publications/lobligation-verte-homeopathie-incantation/, accessed 24 August 2020.

16. In France, investments in listed green funds amount to $€ 23$ billion, or 1.3 per cent of assets under management. See https://www.novethic.fr/actualite/ finance-durable/isr-rse/verdir-le-systeme-financier-une-nouvelle-mission-pour -les-banques-centrales-147174.html, accessed 24 August 2020.

17. In an interview on 9 July 2019, entitled "Philippe Zaouati: l'impact réel de la finance durable est très faible" [Philippe Zaouati: the real impact of sustainable finance is very low]. See https://www.rsedatanews.net/article/article-finance -responsable-esg-isr-philippe-zaouati---20190709-2236, accessed 24 August 2020.

18. Passive management for a fund consists of investing in a portfolio of assets, "replicating" an index such as the MSCI World, the Euro Stoxx 600, or the CAC 40. This method reduces management costs and aligns the manager's practice with the market "trend".

19. See https://theshiftproject.org/wp-content/uploads/2019/07/2019-07 _Observatoire-173_Deux-sons-de-cloche-sur-la-mat\%C3\%A9rialit\%C3\%A9-du -risque-climat_The-Shift-Project.pdf, accessed 20 August 2020.

20. Ibid., p. 11.

21. See http://www.oecd.org/environment/fossil-fuel-support-is-rising-again-in-a -threat-to-climate-change-efforts.htm - and the IEA-OECD report on the subject at http://www.oecd.org/fossil-fuels/publication/, both accessed 24 August 2020.

22. See https://alaingrandjean.fr/wp-content/uploads/2015/06/Rapport-CANFIN -GRANDJEAN-FINAL-18062015.pdf, accessed 24 August 2020.

23. See https://www.lesechos.fr/2016/06/omt-la-bce-reste-sous-la-surveillance -appuyee-du-juge-allemand-209962, accessed 24 August 2020.

24. See, for example, https://www.lemonde.fr/international/article/2019/07/16/devant -le-parlement-europeen-ursula-von-der-leyen-promet-un-green-deal-pour-l-ue 5489898_3210.html, accessed 24 August 2020.

25. See https://alaingrandjean.fr/2019/05/14/mandat-bce-politique-monetaire -ecologique/.

26. This public investment expenditure, even financed by public banks, will weigh on the public deficit, as calculated today. I have shown in my last book that it is possible to interpret European procedures intelligently to get around this apparent difficulty. See Alain Grandjean, Marion Cohen and Kevin Puisieux, Agir sans Attendre: Notre Plan de Climat [Act Without Delay: Our Climate Plan], published by Les Liens qui Libèrent, 2019.

27. If necessary, and in order to avoid any legal challenge, paragraph 2 of Article 123 could be supplemented by the following sentence: "By way of derogation from the above, the European Central Bank is authorized to acquire, in significant volumes and on preferential terms, debt instruments issued by the European Investment Bank in support of investments in the ecological transition".

28. For more details on this proposal, see https://lvsl.fr/que-faut-il-changer-dans-les -traites-europeens-en-matiere-monetaire/ - and http://www.bsi-economics.org/ 950-role-politique-monetaire-, accessed 24 August 2020.

29. It is imperative to take into account the sociological realities on these subjects, even if nothing is to be expected from the Bundesbank's leaders - see the interview with its current chief Jens Weidmann: https:/www.lalibre.be/economie/ conjoncture/la-politique-monetaire-ne-doit-pas-servir-les-objectifs-climatiques -bundesbank-5db85c9a9978e218e3854e91, accessed 24 August 2020. 
30. See https://webstore.iea.org/world-energy-investment-2019, accessed 24 August 2020.

31. See https://www.banktrack.org/article/banking_on_climate_change_fossil_fuel finance_report_card_2019, accessed 24 August 2020 .

32. The regulator requires banks to hold a minimum capital based on the amount of their risk-weighted RWAs.

33. See https://www.novethic.fr/actualite/finance-durable/isr-rse/les-banques-de -france-et-d-angleterre-appellent-a-plus-de-regulation-du-secteur-financier-face -au-risque-climatique-145673.html, accessed 24 August 2020.

34. See Jakob Thomä, Kyra Gibhardt, "Quantifying the potential impact of a green supporting factor or brown penalty on European banks and lending”, Journal of Financial Regulation and Compliance, 8 July 2019.

35. The CRR 2 (Capital Requirements Regulation 2) and CRD 5 (Capital Requirements Directive 5). 